\title{
Pengaruh Model Pembelajaran Matematika Realistik Berbantuan Alat Peraga Terhadap Kemampuan Pemahaman Geometri Ditinjau Dari Gaya Belajar Visual Spasial Siswa SD Kelas V Di Kecamatan Pasar Kemis Kabupaten Tangerang
}

\author{
Basiran $^{1}$, Supriadi ${ }^{2}$ dan Suroyo ${ }^{1}$ \\ ${ }^{1}$ Universitas Terbuka, Indonesia \\ ${ }^{2}$ Universitas Pendidikan Indonesia, Indonesia \\ Email korepondensi: 530035456@ecampus.ut.ac.id
}

\begin{abstract}
ABSTRAK
Penelitian ini dilatarbelakangi adanya temuan mengenai rendahnya kemampuan pemahaman matematis siswa SD dan masih terdapat siswa yang pasif dalam proses pembelajaran. Pendekatan pembelajaran dapat mengarahkan siswa untuk aktif dalam proses pembelajaran adalah pendekatan Realistic Mathematics Education (RME) berbantuan alat peraga. Berdasarkan penelitian sebelumnya yang relevan, peningkatan pembelajaran lebih tinggi dibandingkan siswa yang mendapatkan pembelajaran konvensional. Populasi penelitian ini adalah seluruh siswa siswa kelas V di kecamatan Pasarkemis Kabupaten Tangerang tahun pelajaran 2020/2021dan tekning pengambilan sampel dalam penelitian ini yaitu cluster random sampling sehingga diperoleh dua kelompok secara acak yaitu kelompok eksperimen dan kelompok kontrol. Kedua kelompok tersebut diberikan perlakuan yag berbeda. Penelitian ini bertujuan untuk mengetahui: (1) Perbedaan kemampuan pemahaman matematis siswa yang menggunakan pendekatan RME berbantuan alat peraga lebih baik dan pendekatan ekspositori; (2) mengetahui ada tidaknya interaksi antara pendekatan pembelajaran dengan gaya belajar visual spasial (tinggi,rendah) terhadap kemampuan pemahaman matematika siswa; dan (3) mengeahui perbedaan kemampuan pemahaman konsep matematis siswa yang menggunakan model RME berbantuan alat peraga dan pendekatan ekspositori berdasarkan gaya belajar visual spasial. Hasil penelitian menunjukkan: (1) kemampuan pemahaman matematis siswa yang menggunakan pendekatan RME berbantuan alat peraga lebih baik daripada siswa yang menggunakan pendekatan ekspositori. (2) terdapat interaksi antara pendekatan pembelajaran dan kemampuan matematika awal (tinggi, sedang, rendah) terhadap kemampuan pemahaman matematika siswa. (3) terdapat perbedaan kemampuan pemahaman konsep matematis siswa yang menggunakan model RME berbantuan alat peraga dan pendekatan ekspositori berdasarkan gaya belajar visual spasial
\end{abstract}

Kata Kunci: RME, alat peraga, visual spasial

\section{ABSTRACT}

This research is motivated by the findings regarding the low mathematical understanding ability of elementary school students and there are still students who are passive in the learning process. The learning approach that can lead students to be active in the learning process is the Realistic Mathematics Education (RME) approach with the aid of teaching aids. Based on previous relevant research, the increase in learning is higher than students who get conventional learning. The population of this study was all fifth grade students in the Pasarkemis sub-district, Tangerang Regency for the 2020/2021 academic year and the sampling technique in this study was cluster random sampling so that two groups were obtained randomly, namely the experimental group and the control group. The two groups were given different treatment. This study aims to determine: (1) differences in students' mathematical understanding abilities using the visual aid-assisted RME approach and the 
expository approach; (2) to determine whether there is an interaction between the learning approach and visual spatial learning styles (high, low) on students' mathematical understanding abilities; (3) knowing the differences in the ability to understand mathematical concepts of students using the RME model assisted by visual aids and an expository approach based on visual-spatial learning styles. The results showed: (1) The mathematical understanding ability of students who used the visual aid-assisted RME approach was better than students who used the expository approach. (2) There is an interaction between the learning approach and the initial mathematical ability (high, medium, low) on the students' mathematical understanding ability. (3) There are differences in the ability to understand mathematical concepts of students who use the RME model assisted by visual aids and an expository approach based on visual spatial learning styles

Keywords: education, innovation, international, mathematics, research

\section{PENDAHULUAN}

Matematika mempunyai peran penting dalam segala aspek kehidupan manusia. Banyak hal dalam kehidupan sehari-hari yang berhubungan dengan matematika terutama pada abad ke-20 ini, sehingga matematika menjadi salah satu mata pelajaran wajib di sekolah dasar (Wulandari \& Sulasmono, 2020). Program pendidikan yang dapat mengembangkan kemampuan berpikir kritis, sistematis, logis dan kreatif adalah matematika (Sulestry \& Baharuddin, 2019). Kenyataannya bahwa matematika dipandang sebagai mata pelajaran yang sulit dipahami oleh siswa, hal ini didukung dengan banyaknya siswa yang tidak menyukai pembelajaran ini (I. Fauzi \& Arisetyawan, 2020). Ketidaksukaan siswa pada mata pelajaran matematika akan berdampak pada rendahnya semangat dan motivasi, belajar, tidak dapat menguasai materi pelajaran, bahkan menghindari mata pelajaran, mengabaikan tugas dari guru sehingga terjadi penurunan nilai belajar dan prestasi belajar siswa, adanya anggapan bahwa matematika itu sulit disebabkan karena pembelajaran matematika selama ini disampaikan kepada siswa secara informatif, artinya siswa hanya memperoleh informasi dari guru saja sehingga derajat kemelekatannya dapat dikatakan rendah sehingga guru harus dapat mengajarkan pembelajaran yang bermakna (I. Fauzi \& Arisetyawan, 2020).

Rendahnya hasil belajar peserta didik dapat dilihat pada hasil test matematika semester 2 tahun pelajaran 2020/2021 pada salah satu sekolah dasar negeri yang berlokasi di kecamatan Pasarkemis, terdapat 73,3\% siswa mendapat nilai di bawah KKM, sehingga 50\% lebih siswa memenuhi standar Kriteria Ketuntasan Minimal, belum tercapainya standar minimal atau kelulusan karena proses pembelajaran matematika kurang maksimal yang disebabkan oleh berbagai faktor baik dari guru, siswa, media atau alat bantu pembelajaran maupun kontennya. Lebih lanjut yang menjadi masalah dalam pembelajaran matematika antara lain guru belum inovatif menggunakan, siswa mengalami kejenuhan selama proses pembelajaran, guru kurang melibatkan siswa untuk aktif memanipulasi benda-benda sehingga siswa mengalami kesulitan dalam memahami konsep yang diajarkan, penggunaan sumber belajar yang serasi, siswa cenderung pasif, siswa hanya terbiasauntuk menghafal konsep, siswa jarang bertanya jika ada materi yang belum dipahami, takut dan enggan menjawab pertanyaan yang diberikan guru, siswa tidak memahami materi -materi prasyarat, siswa tidak mengoraganisasi keterkaitan antar bangun berdasar sifat-sifatnya, akibatnya prestasi belajar siswa dalam geometri khususnya bangun ruang rendah (A. Fauzi \& Haeriah, 2021). Ilmu geometri membuat takut untuk anakanak mulai usia 9 tahun ke atas, karena ilmu geometri yang dipelajari sudah tidak lagi menyenangkan, karena banyak teori - teori yang mereka hapalkan, sehingga hasil belajar menjadi rendah (Rosiyanti et al., 2020).

Pembagian materi matematika yang harus dipelajari oleh siswa terdiri dari empat bidang, 
yaitu aljabar, aritmatika, geometri dan analisis, materi geometri ruang yang dipelajari yaitu mengenai bangun ruang sisi datar dan bangun ruang sisi lengkung (Hasanah et al., 2018). Geometri adalah salah satu materi wajib dalam proses pembelajaran di sekolah dasar(Sulestry \& Baharuddin, 2019). Rendahnya nilai matematika merupakan masalah penting yang harus dicari solusinya. Dengan demikian guru harus dapat memilih dan menggunakan model pembelajaran yang dapat menunjang siswa dalam memahami materi yang diajarkan (Nur'aeni L et al., 2020). Salah satu cara yang dapat diterapkan untuk mendekatkan matematika dengan dunia anak Sekolah Dasar adalah dengan menggunakan Pendekatan Matematika Realistik (PMR) yang merupakan gagasan dari matematikawan dan pendidik adalah Profesor Hans Freudenthal yaitu menempatkan matematika sebagai suatu bentuk aktivitas manusia yang menekankan pada kebermaknaan ilmu pengetahuan (Wulandari \& Sulasmono, 2020). Selanjutya pendapat yang serupa yaitu bahwa pendekatan Realistic mathematic Education (RME) pada mata pelajaran matematika merupakan suatu bentuk aktivit manusia, dimana matematika harus dihubungkan dengan kenyataan, dekat dengan siswa dan relevan dengan kehidupan sehari-hari(Haryonik \& Bhakti, 2018) .

Pembelajaran matematika pada sekolah dasar materi pelajaran yang dipelajari yaitu luas permukaan kubus dan balok dimulai dengan pembahasan mengenai pengertian, sifat-sifat, jaring-jaring, luas permukaan, volume dan keliling serta unsur-unsurnya . Awal pembelajaran materi ini peserta didik harus mengetahui konsep-konsep dasar pada kubus dan balok sehingga saat masuk dalam penyelesaian masalah siswa akan mudah menyelesaikannya. Untuk membantu dan mempermudah pemahaman konsep - konsep luas permukaan balok dan kubus perluberkolaborasi dengan alat bantu pembelajaran. Pembelajaran yang dikolaborasi dengan pemanfaatan alat bantu pembelajaran akan menjadi strategi pembelajaran yang efektif dan dapat diterima oleh siswa(Nurrita, 2018). Gaya belajar sebagai cara seseorang untuk mengatur, menyerap dan mengolah informasi dari suatu proses pembelajaran, sehingga gaya belajar sangat berpengaruhi terhadap kemampuan berpikir kritis seorang siswa dalam proses pembelajaran matematika (Hidayati \& Wahyuni, 2020).

\section{METODE PENELITIAN}

Subjek dalam penelitian ini yait seluruh siswa kelas V SD Negeri di Kecamatan Pasar Kemis Kabupaten Tangerang. Teknik pengembilan sampel dalam penelitian ini yaitu sampling acak sederhana. Data diperoleh dari hasil tes pemahaman geometri dan angket gaya belajar visual spasial siswa. Teknik analisis data yang digunakan yaitu Analisis Varians Dua Jalan dan uji lanjut (post hoc).

\section{HASIL DAN PEMBAHASAN}

Setelah uji prasayarat yang meliputi uji normalitas dan homogenitas terpenuhi selanjutnya dilakukan uji hipotesis. Pengujian hipotesis dilakukan untuk mengetahui pengaruh interaksi antara penggunaan alat peraga matematika pada sisi datar luas permukaan balok dan kubus terhadap kemampuan pemahaman konsep geometri serta mengetahui perbedaan masingmasing kelompok sampel berdasarkan kategori gaya belajar. Dalam pengujian hipotesis menggunakan teknik uji two way anova dengan bantuan SPSS. Hasil pengujian hipotesis dapat dilihat pada tabel berikut ini: 


\begin{tabular}{|c|c|c|c|c|c|}
\hline \multicolumn{6}{|c|}{$\begin{array}{l}\text { Tabel } 1 \text { Uji Two Way Anova } \\
\text { Tests of Between-Subjects Effects }\end{array}$} \\
\hline \multicolumn{6}{|c|}{ Dependent Variable: Nilai } \\
\hline Source & $\begin{array}{l}\text { Type III Sum of } \\
\text { Squares }\end{array}$ & Df & Mean Square & $\mathrm{F}$ & Sig. \\
\hline Corrected Model & $2465.344^{\mathrm{a}}$ & 3 & 821.781 & 18.747 & .000 \\
\hline Intercept & 195156.281 & 1 & 195156.281 & 4452.083 & .000 \\
\hline Kelas & 282.031 & 1 & 282.031 & 6.434 & .017 \\
\hline V.spacial & 657.031 & 1 & 657.031 & 14.989 & .001 \\
\hline Kelas * V.spacial & 1526.281 & 1 & 1526.281 & 34.819 & .000 \\
\hline Error & 1227.375 & 28 & 43.835 & & \\
\hline Total & 198849.000 & 32 & & & \\
\hline Corrected Total & 3692.719 & 31 & & & \\
\hline
\end{tabular}

Berdasarkan hasil analisis ANOVA dua jalur pada tabel 4,6 dengan taraf signifikansi 0.05 diperoleh bahwa: Berdasakan hasil ANOVA dua jalur pada baris gaya belajar diperoleh nilai signifikansi sebesar $0.000<0.05$. Artinya terdapat perbedaan kemampuan pemahaman konsep geometri berdasaran gaya belajar. Pada baris kelompok diperoleh nilai signifikansi sebesar $0.017<0.05$, artinya terdapat perbadaan kemampuan pemahaman konsep geometri antara kelompok eksperimen dan kelompok kontrol. Pada baris gaya belajar *diperoleh nilai dignifikansi sebesar $0.001<0,05$, itu artinya terdapat pengaruh interaksi yang signifikan antara model realistik matematik education berbantuan alat peraga pembelajaran dan gaya belajar terhadap kemampuan pemahaman konsep geometri.

Tabel 2 Rangkuman Hasil Uji lanjut (Post-hoc)

\begin{tabular}{|c|c|c|c|c|c|c|c|}
\hline \multicolumn{8}{|c|}{ Pairwise Comparisons } \\
\hline \multicolumn{8}{|c|}{ Dependent Variable: Nilai } \\
\hline \multirow[t]{2}{*}{ V.spacial } & \multirow[t]{2}{*}{ (I) Kelas } & \multirow[t]{2}{*}{ (J) Kelas } & \multirow{2}{*}{$\begin{array}{c}\text { Mean } \\
\text { Difference } \\
(\mathrm{I}-\mathrm{J})\end{array}$} & \multirow[t]{2}{*}{$\begin{array}{l}\text { Std. } \\
\text { Error }\end{array}$} & \multirow[t]{2}{*}{ Sig. $^{b}$} & \multicolumn{2}{|c|}{$\begin{array}{l}95 \% \text { Confidence } \\
\text { Interval for Difference }\end{array}$} \\
\hline & & & & & & $\begin{array}{l}\text { Lower } \\
\text { Bound }\end{array}$ & $\begin{array}{l}\text { Upper } \\
\text { Bound }\end{array}$ \\
\hline \multirow[t]{2}{*}{ Tinggi } & RME & Konvensional & $19.750^{*}$ & 3.310 & .000 & 12.969 & 26.531 \\
\hline & Konvensional & RME & $-19.750^{*}$ & 3.310 & .000 & -26.531 & -12.969 \\
\hline \multirow[t]{2}{*}{ Rendah } & RME & Konvensional & $-7.875^{*}$ & 3.310 & .024 & -14.656 & -1.094 \\
\hline & Konvensional & RME & $7.875^{*}$ & 3.310 & .024 & 1.094 & 14.656 \\
\hline \multicolumn{8}{|c|}{ Based on estimated marginal means } \\
\hline \multicolumn{8}{|c|}{ *. The mean difference is significant at the .050 level. } \\
\hline
\end{tabular}

Berdasarkan uji lanjut tuckey dapat diketahui bahwa:

a. Kelompok siswa kelas yang diajar melalui pendekatan RME berbantuan alat peraga dan kelompok siswa yang diajar melalui pendekatan ekspositori pada kategori gaya belajar visual spasial tinggi, berdasarkan hasil uji Post-hoc diperoleh nilai signifikansi sebesar $0,000<0,05$, artinya terdapat perbedaan yang signifikan. Sedangkan selisih rataannya mean-difference yaitu sebesar 19.750, dengan demikan dapat dinyatakan bahwa kemampuan pemahaman konsep geometri siswa yang diajar dengan pendekatan RME berbantuan alat perga yang memilki gaya belajar visual spasial tinggi lebih baik dibandingkan siswa yang memperoleh pembelajaran ekspositori

b. Kelompok siswa yang diajar dengan pendekatan RME berbantuan alat peraga dan kelompok siswa yang diajar dengan pendekatan ekspositori pada kategori gaya belajar visual spasial rendah memperoleh nilai signifikansi sebesar $0,024<0,05$, artinya ada perbedaan yang signifikan. Selisih rataan yang diperoleh yaitu sebesar 7.875 dengan 
demikian dapat dismpulkan bahwa kemampuan pemahaman konsep geometri siswa yang memiliki gaya belajar visual spasial tinggi yang diajar dengan pendekatan RME berbantuan alat peragatidak lebih baik dibandingkan siswa yang diajar dengan pendekatan ekspositori.Setelah diketahui adanya pengaruh interaksi yang signifikan, untuk mengetahui perbedaan rata-rata pada masing-masing kelompok sampel dilakukan uji lanjutan. Uji lanjutan dalam penelitian ini menggunakan teknik uji post hoc. Hasil uji lanjutdapat dilihat pada tabel berikut:

Hasil analisis statatistik melalui uji anova dua jalan diperoleh nilai signifikansi sebesar $0.000<$ 0.05 maka disimpulkan bahwa terdapat perbedaan kemampuan pemahaman konsep geometri siswa atara siswa yang memperoleh pembelajaran pendekatan RME berbantuan alat peraga dan pendekatan ekspositori. Berdasarkan perolehan nilai rata-rata siswa memperoleh pendekatan RME berbantuan alat peraga yaitu 81.06 sedangkan pendekatan ekspositori yaitu 75.13.

Kemampuan pemahaman konsep geometri metematis merupakan hasil belajar yang termasuk dalam kategori pemahaman. Kemampuan pemahamn konsep geometri matematis dapat meningkat manakala disajikan pembelajaran yang tepat. Silfanus Jelatu dalam (Jelatu \& Kurnila, 2019) pola pembelajaran dan metode yang tepat yang diterapkan oleh guru akan berpengaruh terhadap keberhasilan siswa dalam memahami matematika salah satu pola dan metode pembelajaran yang dapat meningkatkan kemampuan pemahaman konsep geometri matematis yaitu penggunaan alat peraga berbasis konsep luas permukaan balok dan kubus.isi hasil dan pembahasan ditulis dengan font Times New Roman 11. Hasil bukan merupakan data mentah, melainkan data yang sudah diolah/dianalisis dengan metode yang telah ditetapkan. Pembahasan adalah perbandingan hasil yang diperoleh dengan konsep/teori yang ada dalam tinjauan pustaka. Isi hasil dan pembahasan mencakup pernyataan, tabel, gambar dan sebagainya.

Terdapat perbedaan kemampuan pemahaman konsep geometri antara siswa yang memiliki visual spasial tinggi dan rendah. Hasil pengujian hipotesis melalui anova 2 jalur diperoleh nilai signifikansi sebesar $0,001<0,05$ artinya terdapat perbedaan yang signifikan..

Kemampuan pemahaman konsep geometri tidak hanya dipengaruhi oleh faktor pola pembelajaran yang disajikan guru. Faktor lain yang mempengaruhi kemampuan pemahaman konsep matematis yaitu gaya belajar. Perbedaan gaya belajar siswa mempengaruh cara bagaimana siswa belajar. Pada siswa dengan kategori gaya belajar visual spasial mereka lebih mudah memahami materi dengan cara mendengar penjelasan dari guru. Berbeda halnya dengan siswa yang memiliki gaya belajar visual spasial. Siswa dengan gaya belajar visual akan terbantu dengan cara belajar menggunakan gambar atau bentuk visual sedangkan siswa dengan gaya belajar kinestetik mereka sangat diuntungkan apabila memperoleh pembelajaran yang memadukan antara audio dan visual.

Terdapat pengaruh interaksi antara penggunaan pendekatan RME berbantuan alat peraga dan gaya belajar terhadap kemampuan pemahaman geometris. Hal tersebut dinyatakan berdasarkan hasil anova dua jalur dengan perolehan nilai signifikansi sebesar $0.000<0.05$. Kemampuan pemahaman geometri merupakan hasil belajar yang lebih tinggi daripada ingatan. Menurut Purwanto dalam (Nur'aeni L et al., 2020) pemahaman adalah tingkat pengetahuan di mana siswa mampu memahami konsep, situasi dan fakta yang diketahuinya". Kemampuan pemahaman konsep geometri dipengaruhi oleh beberapa faktor baik eksternal maupun internal. Faktor eksternal yang mempengaruhi kemampuan pemahaman konsep geometri yaitu pendekatan pembelajaran sedangkan faktor internal yang mempengaruhi kemampuan pemahaman matematis yaitu gaya belajar siswa. Pendekatan pembelajaran atau pola pembelajaran saling berhubungan dengan gaya belajar yang dimiliki siswa. maka dari itu pendekatan pembelajaran yang tepat akan menguntungkan bagi siswa dengan gaya belajar tertetentu.

Terdapat perbedaan kemampuan pemahaman konsep geometri antara siswa yang 
memperoleh pembelajaran dengan pendekatan RME berbantuan alat peraga dan siswa yang memperoleh pembelajaran ekspositori pada kategori gaya belajar visual spasial tinggi. Hasil perhitungan melalui uji Post-hoc diperoleh nilai signifikansi sebesar $0.000<0.05$ sedangkan selisih rataanya yaitu sebesar 19.750

Pembelajaran dengan pendekatan RME menyajikan pembelajaran dengan menekankan pada pengunaan benda-benda konkret sebagai penunjang belajar. Siswa yang memiliki gaya belajar visual spasial tinggi menjadi dapat berkembang kemampuan pemahamn konsep matematikanya karena lebih terbantu dengan penggunanan pendekatan RME. Berdasarkan analisis statistik dan kajian teoritis yang telah dirumuskan sebelumnya maka dapat disimpulkan bahwa kemampuan pemahaman konsep geometri matemtis pada siswa yang memiliki gaya belajar visual spacial tinggi yang menggunakan pendekatan RME lebih baik daripada siswa yang menggunakan pendekatan ekspositori.

Kemampuan pemahaman konsep geometri siswa yang memperoleh pembelajaran konvensional lebih baik daripada siswa yang memperoleh pembelajaran dengan pendekatan RME berbantuan alat peraga. Hal ini ditunjukan dengan hasil uji Post hoc dimana nilai signfikansi yang diperoleh yaitu sebesar $0.024<0.05$ dan selisih rataannya yaitu sebesar 7.857 .

Gaya belajar visual spacial berkaitan erat dengan kemampuan geometri. Siswa yang memiliki gaya belajar visual spacial rendeh cenderung sulit jika diterapkan pembelajaran dengan pendekatan RME yang mengusung realitas siswa. Dengan demikian pada siswa yang memiliki gaya belajar visual rendah mereka cenderung sulit untuk mempelajari matematika jika diterapkan pendekatan RME berbantuan alat peraga.

\section{KESIMPULAN}

Berdasarkan hasil penelitian dan pembahasan maka dapat diambil beberapa kesimpulan penelitian sebagai berikut:

1. Terdapat perbedaan pemahaman konsep geometri antara siswa yang memperoleh pembelajaran model relastik matamatic education (RME) dengan berbantuan alat peraga siswa yang memperoleh pembelajaran dengan pendekatan konvensional.

2. Terdapat perbedaan pemahaman konsep geometri antara siswa yang memiliki gaya belajar visual spasial tinggi dan rendah.

3. Terdapat pengaruh interaksi antara pendekatan pembelajaran dangaya belajar terhadap kemampuan pemahaman konsep geometri.

4. Pada siswa yang memiliki gaya belajar visual spasial tinggi yang memperoleh pembelajaran dengan pendekatan RME berbantuan alat peraga kemampuan pemahaman konsep geometri lebih baik dari siswa yang memproleh pendekatan ekspositori

5. Kemampuan pemahaman konsep geometri siswa yang memiliki gaya belajar visual spasial rendah yang memperoleh pembelajaran ekspositori lebih baik daripada siswa yang memperoleh pembelajaran denganpendekatan RME berbantuan alat peraga

\section{DAFTAR PUSTAKA}

Fauzi, A., \& Haeriah. (2021). Kesulitan Siswa Sekolah Dasar pada Materi Geometri Bangun Ruang Ditinjau dari Persepsi Guru. DIKMAT: Jurnal Pendidikan Matematika, 1(2), 1723.

Fauzi, I., \& Arisetyawan, A. (2020). Analisis Kesulitan Belajar Siswa pada Materi Geometri Di Sekolah Dasar. Kreano, Jurnal Matematika Kreatif-Inovatif, 11(1), 27-35. https://doi.org/10.15294/kreano.v11i1.20726

Haryonik, Y., \& Bhakti, Y. B. (2018). Pengembangan Bahan Ajar Lembar Kerja Siswa Dengan Pendekatan Matematika Realistik. MaPan, 6(1), 40-55. 
https://doi.org/10.24252/mapan.2018v6n1a5

Hasanah, H. W., Fatmawati, \& Marlina. (2018). Peningkatan Ketahanan Duduk dan Pengurangan Perilaku Meninggalkan Tempat Duduk melalui Teknik Time Out pada Anak Attention Deficit Hyperactivity Disorder. Jurnal Pendidikan Kebutuhan Khusus, 2(1), 26-31.

Hidayati, D. W., \& Wahyuni, A. (2020). Correlation of Resilience and Spatial Ability in Distance Material. Daya Matematis: Jurnal Inovasi Pendidikan Matematika, 8(2), 149153.

Jelatu, S., \& Kurnila, V. S. (2019). Analysis of Translation Understanding from Verbal to Visual on Trigonometry Concept. Formatif: Jurnal Ilmiah Pendidikan MIPA, 9(3), 191202. https://doi.org/10.30998/formatif.v9i3.3663

Nur'aeni L, E., Muharram, M. R. W., Pranata, O. H., \& Apriani, I. F. (2020). SPADE : Model Pembelajaran Geometri di Sekolah Dasar. Indonesian Journal of Primary Education, 4(2), 204-211.

Nurrita, T. (2018). Pengembangan Media Pembelajaran Untuk Meningkatkan Hasil Belajar Siswa. MISYKAT: Jurnal Ilmu-Ilmu Al-Quran, Hadist, Syari'ah Dan Tarbiyah, 3(1), 171. https://doi.org/10.33511/misykat.v3n1.171

Rosiyanti, H., Eminita, V., \& Riski, R. (2020). Desain Media Pembelajaran Geometri Ruang Berbasis Powtoon. FIBONACCI: Jurnal Pendidikan Matematika Dan Matematika, 6(1), 77-86. https://dx.doi.org/10.24853/fbc.6.1.77-86.

Sulestry, A. I., \& Baharuddin, M. R. (2019). Media Pembelajaran Geometri dalam Konsep Behavioristik.

Prosiding Semantik, $43-46$. https://journal.uncp.ac.id/index.php/semantik/article/view/1489

Wulandari, A. I., \& Sulasmono, B. S. (2020). Pengaruh Penggunaan Pendekatan Pendidikan Matematika Realistik (PMR) terhadap Hasil Belajar siswa Sekolah Dasar. Jurnal Pendidikan Dan Pengajaran Guru Sekolah Dasar, 3(1), 78-82. https://doi.org/10.31004/basicedu.v5i2.878 